\title{
Development and Validation Chemometric Assisted Spectrophotometric Method for the Estimation of Ofloxacin and Cefpodoxime Proxetil
}

\author{
Santosh V. Gandhi*, Vrushpriya H. Habde, Shreeyash R. Tapale \\ AISSMS College of Pharmacy, Kennedy Road, Pune- 411001, Maharashtra, India. \\ * For Correspondance: Dr. Santosh V. Gandhi, \\ Professor. AISSMS College of Pharmacy, Kennedy Road, Near R.T.O., Maharashtra, India.
}

\begin{abstract}
Chemometrics is the subdivision of analytical chemistry that uses computational methods for qualitative or quantitative analysis of typically multivariate measurement data. In this study, chemometric assisted UV spectrophotometric method was developed and validated for estimation of Ofloxacin and Cefpodoxime proxetil. Chemometric methods used were principle components regression (PCR) and partial leastsquares regression (PLS) for data analysis. Spectra of Ofloxacin and Cefpodoxime proxetil were recorded between wavelengths of 220 to $320 \mathrm{~nm}$ with wavelength interval of $0.5 \mathrm{~nm}$ in linearity range of $5.0-30.0 \mu \mathrm{g} / \mathrm{ml}$ for both the drugs. The methods were validated as per International Conference on Harmonization Q2 (R1) (ICH) guidelines. These methods were successfully applied for determination of drugs in pharmaceutical formulation (tablet) with no interference of the excipients as indicated by the recovery study results. The proposed methods are simple, rapid and can be easily used as an alternative analysis tool in the quality control as well as in process control of drugs and formulation.
\end{abstract}

Keywords: Ofloxacin, Cefpodoxime proxetil, UV spectroscopy, Chemometrics, PLS, PCR.

\section{INTRODUCTION}

Ofloxacin (OFLOX) is a broad-spectrum fluorinated quinolone antibacterial with IUPAC name(RS)9-fluoro-3-methyl-10-(4-methylpiperazin-lyl)-7-oxo-2,3-dihydro-7H-pyrido $\quad[1,2,3, \quad$-de]-1,4benzoxazine6-carboxylic acid(Fig. 1a) ${ }^{[1]}$. It is used in the treatment of respiratory tract infections, pharyngitis, community-acquired pneumonia, mild to moderate bacterial exacerbation, sexually transmitted diseases, acute and uncomplicated urethral and cervical gonorrhea, urethritis, complicated urinary tract infections, prostatitis ${ }^{[2]}$.

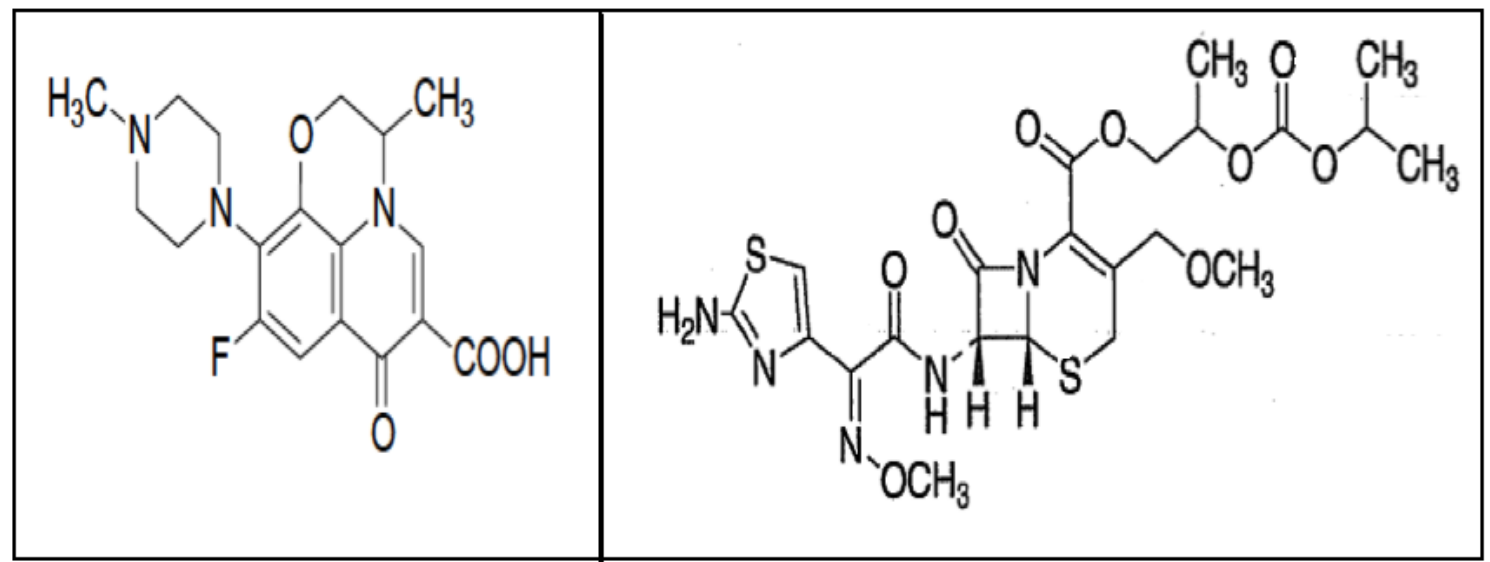

Fig. 1. Chemical structures of Ofloxacin and Cefpodoxime proxetil

Cefpodoxime Proxetil (CP) is a broad spectrum, orally absorbed third generation cephalosporin antibiotic with IUPAC name 1-(isopropoxycarbonyloxy) ethyl $(6 R, 7 R)$-7-[2-(2-amino-4-thiazolyl)- 
(Z)-2-(methoxyimino) acetamido]-3-methoxymethyl-3-cephem-4-carboxylate (Fig. 1b) ${ }^{[1]}$. It is used in the treatment of influenza, meningitis, gonorrhea, pneumonia, tuberculosis, acute otitis media, pharyngitis ${ }^{[2]}$.

The combination of CP and OFLOX has a double mode of action, OFLOX prevents nucleic acid synthesis, while CP inhibits cell wall synthesis and work synergistically with improved patient compliance ${ }^{[2]}$. Cefpodoxime proxetil and Ofloxacin are formulated together in the form of tablet.

Chemometrics is the subdivision of analytical chemistry that uses computational methods for qualitative or quantitative analysis of typically multivariate measurement data ${ }^{[3]}$.

Multivariate statistical analysis methods presume that there is a linear relationship between absorbance and component concentrations. Each method has a calibration step in which the relationship between the spectra and the component concentrations is elucidated from a set of reference samples (calibration set). This step is followed by a prediction step in which the results of the calibration are used to calculate the concentrations from sample spectrum of Validation set ${ }^{[4]}$.PLS1 is a tool for the resolution of mixtures and was developed by S.Wold ${ }^{[5]}$.

Literature survey reveals that there are few reported methods for estimation of CP and OFLOX alone and in combination with other drugs by HPLC ${ }^{[2,6-7]}$ and UV spectrophotometry ${ }^{[8-11]}$. To the best of our knowledge no chemometric assisted UV spectrophotometric method was reported for simultaneous estimation of Ofloxacin and Cefpodoxime proxetil in combination hence the work was undertaken. The multivariate calibration methods investigated in this manuscript include the two most common methods, Principal component regression (PCR) and Partial least squares (PLS)for the determination of OFLOX and CP.

\section{Materials AND Methods}

\section{Instrumentation:}

Double-beam UV-visible spectrophotometer (JASCO V-730, Japan), with matched pair of 1-cm quartz cells was used. 'Spectra Manager' software was utilized for spectra analysis. Computations of PCR and PLS were carried out by using Unscrambler X-10.3 (64 bit) trial version. Microsoft Excel 2010 was used for calculations and storing absorbance data.

\section{Reagents and chemicals:}

Pure drug samples of Ofloxacin and Cefpodoxime proxetil were provided by Twilight Litaka Pharma Ltd, (Pune, MH, India) and Aristo Pharmaceuticals Pvt Ltd, (Mumbai, MH, India), respectively as gift samples. The marketed formulation, CEPODEM-O (Malik Lifesciences Pvt. Ltd, Haridwar, Uttarakhand, India)was procured from local market containing Ofloxacin IP $200 \mathrm{mg}$ and Cefpodoxime proxetil $200 \mathrm{mg}$. Methanol used was of analytical grade (Loba Chemie, Mumbai, MH, India).

\section{Preparation of Standardstock solution:}

Stock solution of OFLOX and CP were prepared by dissolving accurately weighed $10 \mathrm{mg}$ of standard drugs in $10 \mathrm{ml}$ of methanol, separately $(1000 \mu \mathrm{g} / \mathrm{ml})$.Further $5 \mathrm{ml}$ of these solutions were pipetted and diluted to $50 \mathrm{ml}(100 \mu \mathrm{g} / \mathrm{ml})$.

\section{Working standard solution:}

From stock solutions $(100 \mu \mathrm{g} / \mathrm{ml})$ of OFLOX and CP, working standard solutions of 5, 10, 15, 20, 25 and $30 \mu \mathrm{g} / \mathrm{ml}$ for both drugs were obtained.

\section{Preparation of Calibration and Validation sets:}

A total set of 45 mixtures were prepared by combining working standard of OFLOX and CP in their linear concentration range of 5.0-30.0 $\mu \mathrm{g} / \mathrm{ml}$ for both the drugs. From these 30 mixtures were used for calibration set and 15 mixtures were used for validation set (Table No 1).The validation set was randomly selected and its prediction data is presented in Table No 2. The absorbance spectra were recorded in range of 220- $320 \mathrm{~nm}$ at $0.5 \mathrm{~nm}$ interval. The PCR and PLS models were developed utilizing absorption data using Unscrambler software. The first step in multivariate methods (PCR and PLS) involves constructing the calibration matrix. To confirm good predictability of generated model the RMSE plot versus number of factors (PLS method) as indicated in Fig. 2. Mean centering of the 
Development and Validation Chemometric Assisted Spectrophotometric Method for the Estimation of Ofloxacin and Cefpodoxime Proxetil

data was done for getting the optimum results. Leave one out (LOO) cross validation was used in our study for optimizing the number of PCR and PLS components and is calculated using below formula,

$$
\text { RMSECV }=\sqrt{\sum \frac{(\text { Cact-Cpre })^{2}}{I c}}
$$

Where,

RMSECV $=$ Root mean square error of cross validation

Cact $=$ actual concentration of calibration set

Cpre $=$ predicted concentration of validation set

Ic $=$ Total number of samples in calibration set

The selection of the optimum number of LVs was a very important preconstruction step, if the number of factors retained was more than required, more noise would be added to the data; if the number retained was too small, meaningful data that could be necessary for the calibration might be lost ${ }^{[12]}$. After the PLS model has been constructed, it was found that the optimum number of LVs described by the developed models was two as shown in Fig. 2.

Table1. Concentration data of the different mixtures of OFLOX and CP used in the calibration set and validation set.

\begin{tabular}{|c|c|c|c|c|c|}
\hline Mixture No. & OFLOX $\mu \mathrm{g} / \mathrm{ml}$ & $\mathrm{CP} \mu \mathrm{g} / \mathrm{ml}$ & Mixture No & OFLOX $\mu \mathrm{g} / \mathrm{ml}$ & $\mathrm{CP} \mu \mathrm{g} / \mathrm{ml}$ \\
\hline $1 \mathrm{c}$ & 5 & 5 & $24 \mathrm{c}$ & 20 & 30 \\
\hline $2 \mathrm{c}$ & 5 & 10 & $25 \mathrm{c}$ & 25 & 5 \\
\hline $3 \mathrm{c}$ & 5 & 15 & $26 \mathrm{c}$ & 25 & 10 \\
\hline $4 \mathrm{c}$ & 5 & 20 & $27 \mathrm{c}$ & 25 & 15 \\
\hline $5 \mathrm{c}$ & 5 & 25 & $28 \mathrm{c}$ & 25 & 20 \\
\hline $6 \mathrm{c}$ & 5 & 30 & $29 \mathrm{c}$ & 25 & 25 \\
\hline $7 \mathrm{c}$ & 10 & 5 & $30 \mathrm{c}$ & 25 & 30 \\
\hline $8 \mathrm{c}$ & 10 & 10 & $1 \mathrm{v}$ & 5 & 25 \\
\hline $9 \mathrm{c}$ & 10 & 15 & $2 \mathrm{v}$ & 5 & 20 \\
\hline $10 \mathrm{c}$ & 10 & 20 & $3 \mathrm{v}$ & 8 & 14 \\
\hline $11 \mathrm{c}$ & 10 & 25 & $4 \mathrm{v}$ & 10 & 15 \\
\hline $12 \mathrm{c}$ & 10 & 30 & $5 \mathrm{v}$ & 10 & 25 \\
\hline $13 \mathrm{c}$ & 15 & 5 & $6 \mathrm{v}$ & 12 & 6 \\
\hline $14 \mathrm{c}$ & 15 & 10 & $7 \mathrm{v}$ & 13 & 17 \\
\hline $15 \mathrm{c}$ & 15 & 15 & $8 \mathrm{v}$ & 14 & 12.5 \\
\hline $16 \mathrm{c}$ & 15 & 20 & $9 \mathrm{v}$ & 15 & 0 \\
\hline $17 \mathrm{c}$ & 15 & 25 & $10 \mathrm{v}$ & 15 & 8 \\
\hline $18 \mathrm{c}$ & 15 & 30 & $11 \mathrm{v}$ & 15 & 10 \\
\hline $19 \mathrm{c}$ & 20 & 5 & $12 \mathrm{v}$ & 16.5 & 18 \\
\hline $20 \mathrm{c}$ & 20 & 10 & $13 \mathrm{v}$ & 16 & 18 \\
\hline $21 \mathrm{c}$ & 20 & 15 & $14 \mathrm{v}$ & 20 & 5 \\
\hline $22 \mathrm{c}$ & 20 & 20 & $15 \mathrm{v}$ & 20 & 13 \\
\hline $23 \mathrm{c}$ & 20 & 25 & & & \\
\hline
\end{tabular}

$* 1 \mathrm{c}$ to $30 \mathrm{c}$ calibration set; $1 \mathrm{v}$ to $15 \mathrm{v}$ validation set

Table 2. Concentration data of the different mixtures used in the validation set along with its prediction data

\begin{tabular}{|c|c|c|c|c|c|c|c|c|c|}
\hline \multicolumn{2}{|l}{$\begin{array}{l}\text { Expected } \\
\text { Conc. }(\mu \mathrm{g} / \mathrm{ml})\end{array}$} & \multicolumn{4}{|c|}{\begin{tabular}{c}
\multicolumn{4}{c|}{ PLS } \\
\cline { 2 - 10 }
\end{tabular}} & $\begin{array}{c}\text { Predicted Conc. } \\
(\mu \mathrm{g} / \mathrm{ml})\end{array}$ & \multicolumn{2}{c|}{$\%$ Recovery } & \multicolumn{2}{c|}{$\begin{array}{c}\text { Predicted Conc. } \\
(\mu \mathrm{g} / \mathrm{ml})\end{array}$} & \multicolumn{2}{c|}{$\%$ Recovery } \\
\hline OFL & CP & OFL & CP & OFL & CP & OFL & CP & OFL & CP \\
\hline 5 & 25 & 5.142 & 24.698 & 102.84 & 98.79 & 5.142 & 24.698 & 102.84 & 98.79 \\
\hline 5 & 20 & 5.223 & 20.122 & 104.46 & 100.61 & 5.223 & 20.122 & 104.46 & 100.61 \\
\hline 8 & 14 & 8.247 & 13.419 & 103.09 & 95.85 & 8.247 & 13.419 & 103.09 & 95.85 \\
\hline 10 & 15 & 9.993 & 14.459 & 99.93 & 96.39 & 9.993 & 14.459 & 99.93 & 96.39 \\
\hline 10 & 25 & 9.631 & 24.767 & 96.31 & 99.06 & 9.631 & 24.767 & 96.31 & 99.06 \\
\hline
\end{tabular}


Santosh V. Gandhi et al.

\begin{tabular}{|c|c|c|c|c|c|c|c|c|c|}
\hline \hline 12 & 6 & 12.352 & 5.895 & 102.93 & 98.25 & 12.352 & 5.895 & 102.93 & 98.25 \\
\hline 13 & 17 & 13.176 & 17.002 & 101.35 & 100.01 & 13.176 & 17.002 & 101.35 & 100.01 \\
\hline 14 & 12.5 & 14.385 & 12.630 & 102.75 & 101.04 & 14.385 & 12.630 & 102.75 & 101.04 \\
\hline 15 & 0 & 15.512 & -0.507 & 103.41 & 0 & 15.512 & -0.507 & 103.41 & 0 \\
\hline 15 & 8 & 14.669 & 7.653 & 97.79 & 95.66 & 14.669 & 7.653 & 97.79 & 95.66 \\
\hline 15 & 10 & 14.966 & 9.933 & 99.76 & 99.33 & 14.966 & 9.933 & 99.76 & 99.33 \\
\hline 16.5 & 18 & 16.831 & 17.750 & 102.00 & 98.61 & 16.831 & 17.750 & 102.00 & 98.61 \\
\hline 16 & 18 & 15.797 & 18.232 & 98.73 & 101.28 & 15.797 & 18.232 & 98.73 & 101.28 \\
\hline 20 & 5 & 19.468 & 5.481 & 97.34 & 109.62 & 19.468 & 5.481 & 97.34 & 109.62 \\
\hline 20 & 13 & 19.574 & 13.611 & 97.87 & 104.7 & 19.574 & 13.611 & 97.87 & 104.7 \\
\hline
\end{tabular}

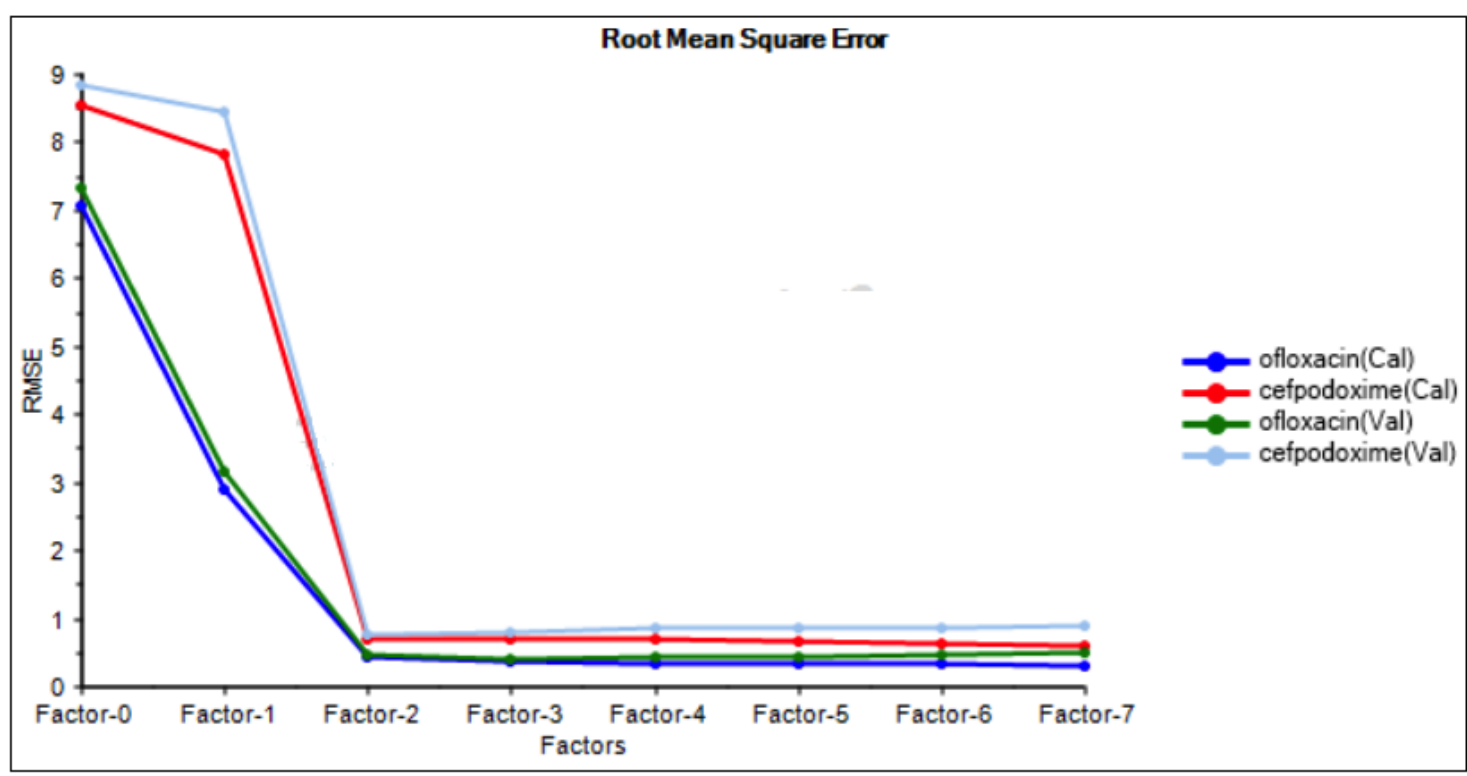

Fig. 2. Plot of RMSE versus number of factors by PLS method

\section{Method validation:}

Developed method was validated as per ICH Q2 (R1) guidelines in terms of linearity, assay, accuracy, precision and limit of detection and quantitation ${ }^{[13]}$. Results were predicted using developed PCR and PLS models.

\section{Linearity:}

The linearity was determined by analyzing six solutions over the concentration range of $5-30 \mu \mathrm{g} / \mathrm{ml}$ for OFLOX and CP. Five replicates per concentrations were analyzed respectively Fig.3 represents linearity curves for both the drugs.

\section{Assay:}

10 tablets of CEPODEM-O were accurately weighed and finely powdered. Tablet powder equivalent to $10 \mathrm{mg}$ of OFLOX (10 $\mathrm{mg}$ of $\mathrm{CP}$ ) was taken and transferred to $10 \mathrm{ml}$ volumetric flask and was diluted to $10 \mathrm{ml}$ with methanol. The solution was sonicated, filtered and $1 \mathrm{ml}$ of filtrate solution was diluted to $10 \mathrm{ml}$ with methanol. Further $1 \mathrm{ml}$ of this solution was diluted to $10 \mathrm{ml}$ with methanol to get final concentration of $10 \mu \mathrm{g} / \mathrm{ml}$ for both the drugs. The procedure was repeated 6 times for tablet formulation. The assay results are presented in Table No 3.

Table 3. Assay of Ofloxacin and Cefpodoxime proxetil by PCR and PLS methods

\begin{tabular}{|l|l|c|c|c|c|c|c|}
\hline Drug & $\begin{array}{l}\text { Amount taken } \\
(\mu \mathrm{g} / \mathrm{ml})\end{array}$ & \multicolumn{2}{|l|}{ Amount found $(\mu \mathrm{g} / \mathrm{ml})$} & \multicolumn{2}{c|}{$\%$ Mean \pm SD } & \multicolumn{2}{c|}{ RSD } \\
\hline & & PCR & PLS & PCR & PLS & PCR & PLS \\
\hline & & 10.2192 & 10.2192 & & & & 0.437 \\
OFLOX & \multirow{2}{*}{10} & 10.2342 & 10.2342 & $10.275 \pm$ & $10.275 \pm$ & 0.437 & \\
& & 10.2639 & 10.2639 & 0.045 & 0.045 & & \\
& & 10.2863 & 10.2863 & & & & \\
& & 10.3410 & 10.3409 & & & & \\
\hline
\end{tabular}


Development and Validation Chemometric Assisted Spectrophotometric Method for the Estimation of Ofloxacin and Cefpodoxime Proxetil

\begin{tabular}{|c|c|c|c|c|c|c|c|}
\hline \hline & & 10.0782 & 10.0782 & & & & \\
$\mathrm{CP}$ & \multirow{3}{*}{10} & 10.2130 & 10.2130 & $10.293 \pm$ & $10.293 \pm$ & 1.360 & 1.360 \\
& & 10.2665 & 10.2666 & 0.140 & 0.140 & & \\
& & 10.3300 & 10.3300 & & & & \\
& & 10.4737 & 10.4737 & & & & \\
\hline
\end{tabular}

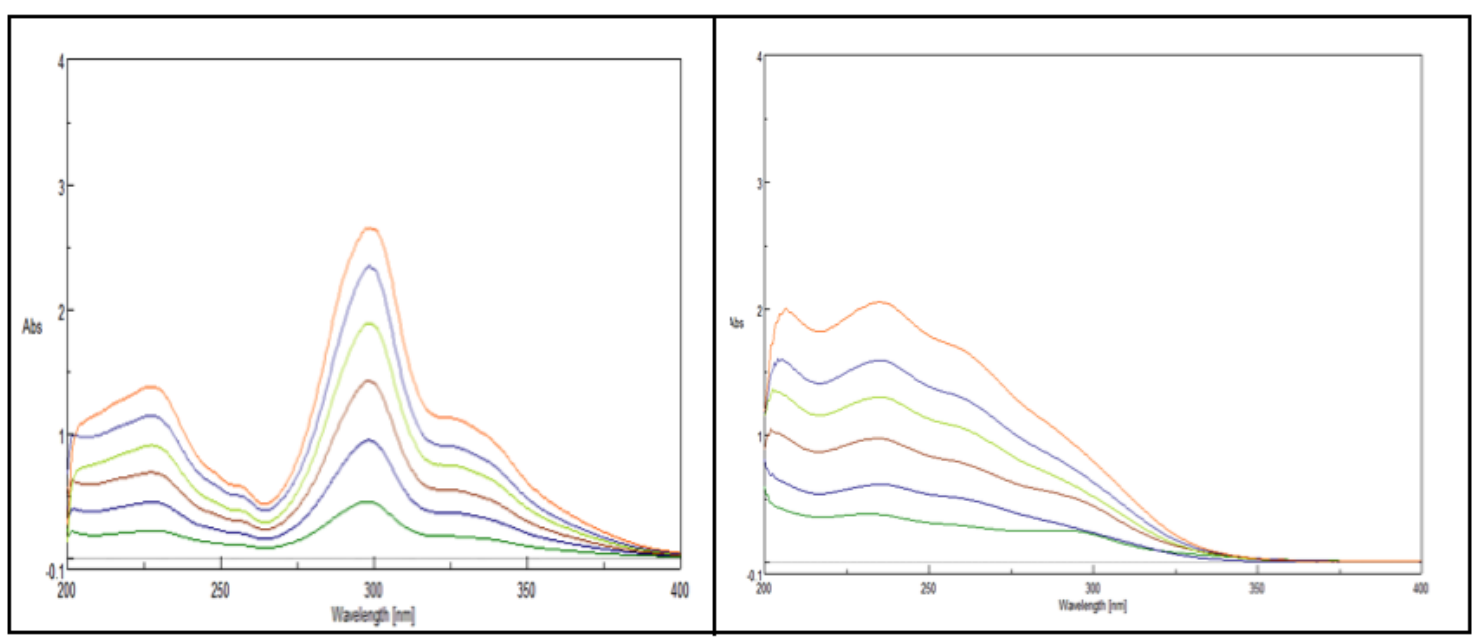

Fig. 3. Linearity curves of Ofloxacin and Cefpodoxime proxetil

\section{Accuracy:}

Accuracy was carried out at 3 different levels of 50,100 and $150 \%$ of assay concentration by adding standard solution to sample solution and calculations for recovery results are presented in Table No 4.

Table 4. Accuracy data of Ofloxacin and Cefpodoxime proxetil by PCR and PLS methods.

\begin{tabular}{|c|c|c|c|c|c|c|c|}
\hline Level & $\begin{array}{l}\text { Amount } \\
\text { taken }(\mu \mathrm{g} / \mathrm{ml})\end{array}$ & \multicolumn{2}{|c|}{$\begin{array}{l}\text { Amount found } \\
(\mu \mathrm{g} / \mathrm{ml})\end{array}$} & \multicolumn{2}{|c|}{$\%$ Mean \pm SD } & \multicolumn{2}{|l|}{$\%$ RSD } \\
\hline \multicolumn{8}{|c|}{ Accuracy data of Ofloxacin by PCR and PLS } \\
\hline & & PCR & PLS & PCR & PLS & PCR & PLS \\
\hline $50 \%$ & 15 & $\begin{array}{l}14.7854 \\
14.8296 \\
14.8389\end{array}$ & $\begin{array}{l}14.7855 \\
14.8296 \\
14.8390\end{array}$ & $\begin{array}{c}14.817 \pm \\
0.028\end{array}$ & $\begin{array}{c}14.818 \pm \\
0.028\end{array}$ & 0.1880 & 0.188 \\
\hline $100 \%$ & 20 & $\begin{array}{l}20.0413 \\
20.1126 \\
20.1362\end{array}$ & $\begin{array}{l}20.0415 \\
20.1129 \\
20.1364\end{array}$ & $\begin{array}{c}20.096 \pm \\
0.049\end{array}$ & $\begin{array}{c}20.096 \pm \\
0.049\end{array}$ & 0.2438 & 0.243 \\
\hline $150 \%$ & 25 & $\begin{array}{l}24.8258 \\
24.8065 \\
24.8667\end{array}$ & $\begin{array}{l}24.8260 \\
24.8068 \\
24.8669\end{array}$ & $\begin{array}{c}24.833 \pm \\
0.030\end{array}$ & $\begin{array}{c}24.833 \pm \\
0.030\end{array}$ & 0.1208 & 0.120 \\
\hline \multicolumn{8}{|c|}{ Accuracy data of Cefpodoxime proxetil by PCR and PLS } \\
\hline & & PCR & PLS & PCR & PLS & PCR & PLS \\
\hline $50 \%$ & 15 & $\begin{array}{l}14.6270 \\
14.6269 \\
14.6405\end{array}$ & $\begin{array}{l}14.6268 \\
14.6267 \\
14.6403\end{array}$ & $\begin{array}{c}14.631 \pm \\
0.007\end{array}$ & $\begin{array}{c}14.631 \pm \\
0.007\end{array}$ & 0.004 & 0.004 \\
\hline $100 \%$ & 20 & $\begin{array}{l}19.7228 \\
19.6896 \\
19.6925\end{array}$ & $\begin{array}{l}19.7223 \\
19.6892 \\
19.6920\end{array}$ & $\begin{array}{c}19.701 \pm \\
0.018\end{array}$ & $\begin{array}{c}19.701 \pm \\
0.018\end{array}$ & 0.009 & 0.091 \\
\hline $150 \%$ & 25 & $\begin{array}{l}24.9871 \\
25.0168 \\
25.0293\end{array}$ & $\begin{array}{l}24.9866 \\
25.0163 \\
25.0288\end{array}$ & $\begin{array}{c}25.011 \pm \\
0.021\end{array}$ & $\begin{array}{c}25.010 \pm \\
0.021\end{array}$ & 0.008 & 0.083 \\
\hline
\end{tabular}

\section{Precision:}

Precision was carried at concentration levels of $5 \mu \mathrm{g} / \mathrm{ml}, 10 \mu \mathrm{g} / \mathrm{ml}$ and $15 \mu \mathrm{g} / \mathrm{ml}$ in three replicates. The results of which are presented in Table No 5. Recovery and \% RSD was calculated. 
Santosh V. Gandhi et al.

Table 5. Results obtained by applying PCR and PLS calibration methods to precision of Ofloxacin and Cefpodoxime proxetil.

\begin{tabular}{|c|c|c|c|c|c|c|c|c|c|c|c|c|c|}
\hline \multirow[t]{2}{*}{\begin{tabular}{|c|} 
Conc \\
of \\
OFLOX \\
\end{tabular}} & \multirow[t]{2}{*}{$\begin{array}{l}\text { Conc } \\
\text { of } \mathrm{CP}\end{array}$} & \multicolumn{2}{|c|}{$\begin{array}{l}\text { Amount found } \\
\text { of OFLOX } \\
(\mu \mathrm{g} / \mathrm{ml})\end{array}$} & \multicolumn{2}{|c|}{$\begin{array}{c}\text { Amount } \\
\text { found of CP } \\
(\mu \mathrm{g} / \mathrm{ml})\end{array}$} & \multicolumn{2}{|c|}{$\begin{array}{c}\% \text { Recovery of } \\
\text { OFLOX }\end{array}$} & \multicolumn{2}{|c|}{$\begin{array}{c}\text { \% Recovery of } \\
\text { CP }\end{array}$} & \multicolumn{2}{|c|}{$\begin{array}{l}\text { \%RSD of } \\
\text { OFLOX }\end{array}$} & \multicolumn{2}{|c|}{$\begin{array}{c}\% \mathrm{RSD} \text { of } \\
\mathrm{CP}\end{array}$} \\
\hline & & PCR & PLS & PCR & PLS & PCR & PLS & PCR & PLS & PCR & PLS & PCR & PLS \\
\hline 5 & 5 & 5.07 & 5.07 & 5.10 & 5.10 & 101.6 & 104.6 & 102.0 & 102.0 & 1.49 & 1.49 & 1.37 & 1.37 \\
\hline 5 & 5 & 5.13 & 5.13 & 5.18 & 5.18 & 102.6 & 107.8 & 103.7 & 103.7 & & & & \\
\hline 5 & 5 & 4.98 & 4.98 & 5.04 & 5.04 & 99.6 & 97.5 & 100.9 & 100.9 & & & & \\
\hline 10 & 10 & 9.65 & 9.65 & 9.95 & 9.95 & 96.5 & 96.5 & 99.5 & 99.5 & 1.35 & 1.35 & 0.97 & 0.97 \\
\hline 10 & 10 & 9.91 & 9.91 & 10.14 & 10.14 & 99.1 & 99.1 & 101.4 & 101.4 & & & & \\
\hline 10 & 10 & 9.83 & 9.83 & 10.09 & 10.09 & 98.3 & 98.3 & 100.9 & 100.9 & & & & \\
\hline 15 & 15 & 14.95 & 14.95 & 15.79 & 15.79 & 99.7 & 99.7 & 105.3 & 105.3 & 0.64 & 0.64 & 0.22 & 0.22 \\
\hline 15 & 15 & 14.76 & 14.76 & 15.72 & 15.72 & 98.4 & 98.4 & 104.8 & 104.8 & & & & \\
\hline 15 & 15 & 14.87 & 14.87 & 15.74 & 15.73 & 99.1 & 99.1 & 104.9 & 104.9 & & & & \\
\hline
\end{tabular}

Limit of detection and quantification (LOD and $L O Q)$ :

The limit of detection and quantitation was calculated from the linearity data using the formula LOD $=3.3 \sigma / \mathrm{S}$ and $\mathrm{LOQ}=10 \sigma / \mathrm{S}$ where $\sigma$ is standard deviation of the $\mathrm{y}$ intercept of linearity equation and $\mathrm{S}$ is slope of the calibration curve of the analyte.

\section{RESULTS AND DISCUSSION}

The overlay of absorption UV spectra of pure OFLOX and CP recorded in methanol in wavelength range of 220-320 nm is shown in the Fig 4. The results depicted good coefficient of determination values $\left(\mathrm{R}^{2}\right)$ and root mean square error of calibration (RMSEC). The coefficient of determination $\left(\mathrm{R}^{2}\right)$ for the relationship between actual values and predicted values of both drugs was higher than 0.9903 indicating good accuracy of the developed method while RMSEC values obtained were relatively low which indicate acceptable precision of analytical method. The generated model showed RMSEC value of 0.4297 .

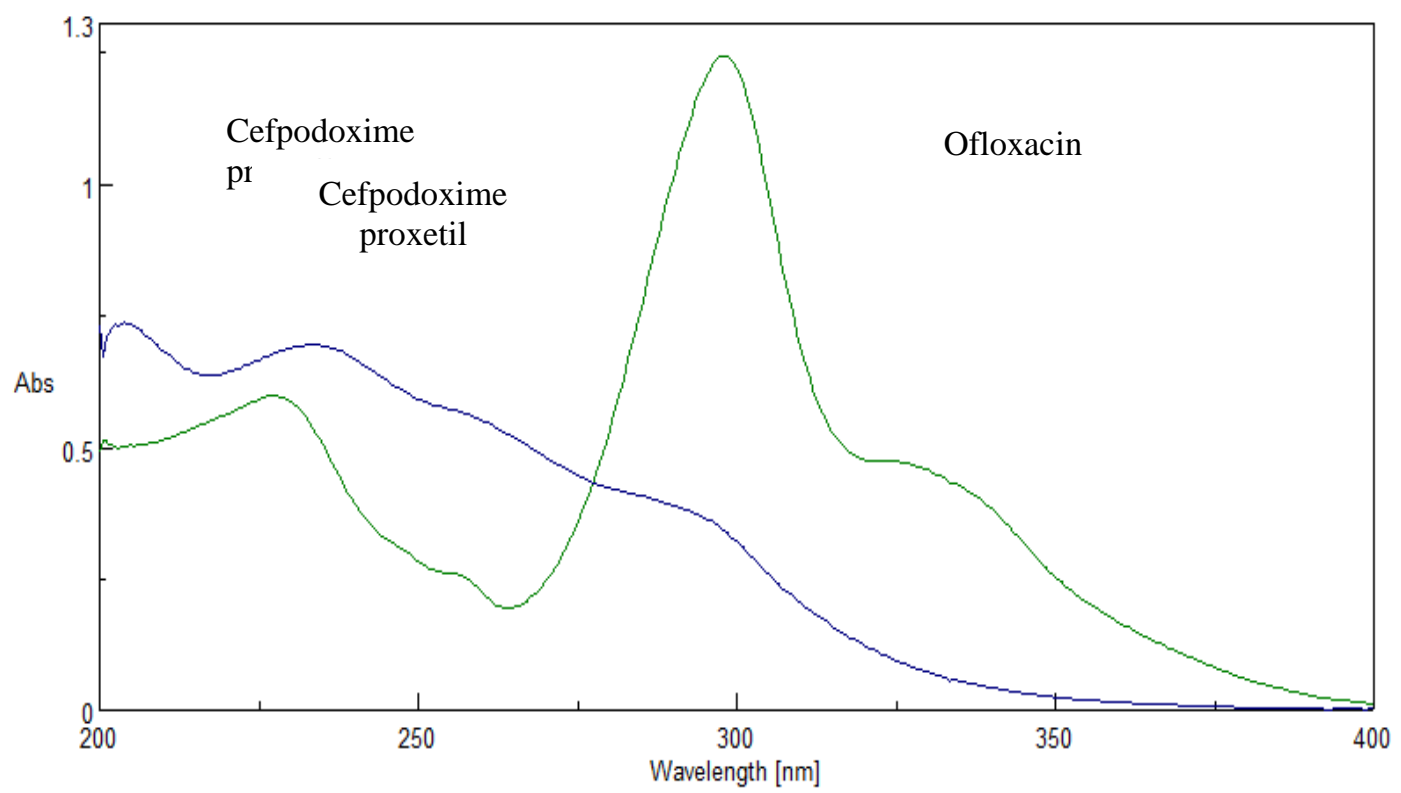

Fig. 4. Overlaid spectra of Ofloxacin and Cefpodoxime proxetil

Linearity of both the drugs was observed between the ranges of 5.0-30.0 $\mu \mathrm{g} / \mathrm{ml}$. Assay results showed almost $100 \%$ recovery with \% RSD of less than 2, while accuracy results were also showed $100 \%$ recovery at various levels. \% RSD for accuracy results was also less than 2 by both PCR and PLS methods. Method was precise. The LOD and LOQ were found to be 1.270 and 3.849 for Ofloxacin and 1.482 and 4.491for Cefpodoxime proxetil, respectively. 


\section{Conclusion}

The proposed method is simple, accurate and suitable for analysis of OFLOX and CP. However, the chemometric methods are less expensive and do not require sophisticated instrumentation and prior separation steps hence, is beneficial than reported HPLC methods. In addition, the proposed methods can be applied for analysis of drugs in quality control lab as well as for in process quality control.

\section{ACKNOWLEDGEMENT}

The authors would like to thank Camo software Ltd., for providing one-month trial of Unscrambler X10.3. Authors are also thankful to Twilight Litaka Pharma Ltd and Aristo Pharmaceuticals Pvt Ltd for providing gift samples of the drugs.

\section{REFERENCES}

[1] Indian Pharmacopoeia,Government of India Ministry of Health and Family Welfare, Sixth Edition, Ghaziabad, Published by The Indian Pharmacopoeia Commission, 2010;Vol 2 and 3:1018-1019, 1808-1809.

[2] Ghode P.D, Pawar S.P. Stability Indicating HPLC Method Development and Validation for the Simultaneous Determination of Cefpodoxime Proxetil and Ofloxacin in its Dosage Forms. IJPBS 2015; 6(2):183-193.

[3] Brereton R.G. Applied Chemometrics for Scientists. John Wiley and Sons Ltd, JCE 2007; 84:1926

[4] KaranjiaJ. Development and Validation of Chemometric Assisted Spectrophotometric Technique for Simultaneous Estimation of Cinitapride and Pantoprazole from Bulk and Combined Dosage Form. IJPSDR. 2015;7(2):198-204.

[5] Yazdi S.A, Abedi M.R, Es'Haghi Z, Kakhki F.J. Simultaneous Determination of Metoprolol and Propranolol Using Chemometric-Assisted Spectrophotometry and High performance Liquid Chromatography. IJPBS. 2012;3(3):532-542.

[6] Chiranjeevi A, Srinivas M. Simultaneous estimation of Cefpodoxime proxetil and Ofloxacin in tablet dosage form using RP-HPLC. JAPS 2014; 4(05):046-050.

[7] Shah D, Talaviya S, Patel M, Simultaneous estimation of Cefpodoxime proxetil and Ofloxacin in pharmaceutical dosage form by RP-HPLC. IJPPS, 2012; 4(3): 627-630.

[8] Patel SA, Patel SA, Simultaneous spectrophotometric determination of Cefpodoxime proxetil and Ofloxacin in tablets. JAPS, 2011; 01 (07): 141-144.

[9] Patil VD, Chaudari RY, Spectrophotometric method for estimation of Cefpodoxime proxetil and Ofloxacin in tablet dosage form by simultaneous equation method. IJPLS2012; 3(9): 1982-1984.

[10] Patel SA, Patel SA, Dual wavelength spectrophotometric method for simultaneous estimation of Ofloxacin and Cefpodoxime proxetil in tablet dosage form. AJPLS, 2011; 1(3): 261-268.

[11] Patel SA, Patel SA, Development and validation of first order derivative spectrophotometric method for simultaneous estimation of Ofloxacin and Cefpodoxime proxetil in tablet dosage form. JPBR, 2011; 1(2): 108-112.

[12] Bhamre P, Pathak A, Rajput S. Simultaneous determination of Doxylamine Succinate, Pyridoxine hydrochloride and Folic acid by Chemometric spectrophotometry. IJPBS; 4(1): 738749.

[13] International Conference on Harmonization. Harmonized Tripartite Guideline, Validation of analytical procedures: Text and Methodology 2005; Q2 (R1): 1-17. 